\title{
DUALISME EKONOMI PADA KREDIT RAKYAT DI YOGYAKARTA PADA TAHUN 1912-1990
}

\author{
Arif Akhyat
}

\begin{abstract}
ABSTRAK
The development of capitalism idea during the colonial prior to the New Order periods need a broader understanding of an historical analysis of popular credit case in Yogyakarta 1912-1990. The establishment of bank in Yogyakarta was already accomplished in the sense that it was owned and managed by state and it sell a large proportion of credit products on the open of financial system in villages. Using the historical critical method, this research seems to be the most appropriate for obtaining meaningful information on descriptions, dynamics, changes and tendencies of the functional relationship between credit systems, state authority and the process of economic transformation in the region of Yogyakarta. Designing with the capitalism system, government credit system was not able to increase a village economy position in Yogyakarta. Popular Credit in the years of 1912-1990 as this research mentioned, is far from what villagers need. Banking system, in practices, was designed to create and produce a subsisten economy. The dual economy experiences of popular credit in Yogyakarta historically had given the state to be the hegemony holder. Popular credit is no more or less as the construct of economic boundaries under the concept of colonialism.
\end{abstract}

Key Words: capitalism, dual economy, popular credit, state hegemony, Yogyakarta

\begin{abstract}
Perkembangan ide kapitalisme pada masa Kolonial sampai Orde Baru membutuhkan pemahaman yang lebih luas mengenai analisis sejarah kasus kredit rakyat di Yogyakarta pada tahun 1912-1990. Pendirian Bank di Yogyakarta, terutama bank yang dimiliki dan dikelola oleh pihak pemerintah, mengeluarkan produk kredit lebih banyak, terutama dalam memenuhi sistem finansial yang terbuka di pedesaan. Dengan menggunakan metode sejarah kritis, penelitian ini dapat memberikan kejelasan (meaningful information) deskripsi, perubahan-perubahan, dinamika, dan hubungan fungsional antara Sistem Kredit, negara, dan transformasi ekonomi, terutama di wilayah Yogyakarta. Berdasarkan pola sistem kapitalisme, sistem kredit yang dikelola pemerintah tidak mampu meningkatkan posisi ekonomi pedesaan Yogyakarta. Kredit rakyat pada tahun 1912-1990 sebagaimana penelitian ini dilakukan, masih jauh dari apa yang dibutuhkan masyarakat desa. Sistem perbankan dalam praktiknya justru dikemas guna menciptakan dan memproduksi ekonomi subsisten. Pengalaman Kredit Rakyat di Yogyakarta secara historis telah memberikan bukti bahwa negara adalah pemegang hegemoni. Kredit rakyat tidak lebih sebagai konstruksi beban-beban ekonomi di bawah konsep kapitalisme.
\end{abstract}

Kata kunci: ekonomi dualisme, kredit rakyat, kapitalisme, hegemoni negara, Yogyakarta

* Jurusan Sejarah, Fakultas Ilmu Budaya, Universitas Gadjah Mada, Yogyakarta 


\section{PENGANTAR}

Boeke dalam melihat perkembangan dan kebijakan ekonomi Indonesia, terutama pada masa Kolonial Belanda, membagi dua model ekonomi yang secara simultan berjalan bersama, yaitu sistem ekonomi subsisten dan sistem ekonomi kapitalis (Boeke, 1936, 1953). Boeke melihat secara kontras antara ekonomi perkebunan Belanda yang dicorakkan dengan sistem kapitalistik yang padat modal dengan ekonomi pedesaan yang bertumpu pada ekonomi pertanian yang terbatas (subsisten). Analisis Boeke ini bertumpu pada relasi sosial dan ekonomi pedesaan. Desa sebagai sistem sosial ekonomi yang tertutup (closed society) cenderung memiliki tingkat ekonomi yang subsisten, sedangkan supradesa dikuasai para pemilik modal dan jaringan kapitalisasi yang terbuka. Hal ini sangat kontras dengan apa yang dikemukakan oleh Furnivall, yaitu di mana pun sistem sosial dan ekonomi dapat hidup bersama sehingga tidak ada relasi positif antara sistem sosial dan ekonomi. Kecenderungan yang muncul justru menciptakan sebuah pluralitas ekonomi karena sistem ekonomi lebih bebas daripada sistem sosial (Furnivall,

1944). Bagi Furnivall, kredit rakyat pedesaan adalah bagian komersialisasi pedesaan sehingga desa dicirikan sebagai ekonomi subsisten dan tertutup tidak benar.

Boeke lebih mengkritisi aliran-aliran kemajemukan ekonomi (plural economy school of thought) yang, menurutnya, tidak memiliki kepekaan politik dan sosial negara jajahan. Boeke mulai menjelaskan konsep dualisme ekonominya dari cara melihat struktur dasar ekonomi masyarakat kolonial yang disebutnya pure economic theory (Boeke, 1953:87-99). Pure economy theory ini didasarkan pada beberapa asumsi, yaitu siapa pun bebas untuk menjadi pelaku ekonomi; ekonomi uang menjadi sistem dasar pelaku ekonomi; sistem ekonomi berlaku di bawah kontrol individu walaupun dalam jaringan organisasi tertentu. Kompetisi dan intervensi menjadi ciri dari sistem pure economy theory di atas, terutama untuk menjelaskan kredit rakyat.

Boeke menyebut ekonomi desa (village economy) sebagai ekonomi subsisten, yaitu sistem ekonomi yang di luar jangkauan ekonomi uang, pasar, dan modal transportasi. Ekonomi kapitalis lebih ditopang oleh jaringan transportasi, lembaga ekonomi (perbankan), ekonomi uang, dan pasar. Melalui kelembagaan sistem ekonomi kapitalis ini, tingkat ketergantungan ekonomi desa terhadap ekonomi kapitalis (living as a parasite on the village economy) menjadi akibat ekonomi yang diciptakan dengan sengaja. Dengan pure economy theory model Boeke ini, perbedaan dan penjarakan ekonomi (economic gap) antara ekonomi kapitalis dan ekonomi desa akan terpelihara.

Bagi Bell, Boeke telah melakukan kesalahan, yaitu kesalahan konseptualisasi terkait dengan kapitalisme (Bell, 1978). Menurut Bell, kapitalisme itu mengalami kesalahan pemaknaan ketika kapitalisme itu diterapkan pada sebuah sistem ekonomi sekaligus dengan sistem sosial budaya. Menurut Bell, juga diperkuat oleh Abdullah dan Soegiarto, kapitalisme itu memiliki logika yang kontradiktif internal satu sama lain berdasarkan sifat transformasi sosial budayanya (Bell, 1978; Abdullah; 2002; Soegiarto, 1993). Namun demikian, model dualisme ekonomi Boeke dengan segala kekurangannya masih menarik untuk dikaji ulang.

Pemikiran Boeke terkait penelitian ini adalah relasi debitur dan kreditur dalam kredit rakyat merupakan relasi yang memproduksi penjarakan antara kapitalis (pemilik modal) dengan kelompok rentan (subsisten). Penjarakan itu sengaja diciptakan dan dipelihara oleh negara, baik kolonial maupun pascakolonial, agar sistem kapitalisme tetap hidup. Tulisan ini mencoba menjawab pertanyan: bagaimana kebijakan kredit rakyat secara historis telah menciptakan bentuk dualisme ekonomi, terutama di Yogyakarta? Tahun 1912 kebijakan tersebut dipakai sebagai cara untuk melihat awal munculnya sistem kredit rakyat melalui Bank Kredit Rakyat di Yogyakarta dan diakhiri pada masa Orde Baru.

Penelitian ini menggunakan metode sejarah kritis. Metode sejarah kritis dalam penelitian ini dipahami sebagai cara merekonstruksi deskripsi sejarah dengan melihat struktur, proses, dan kecenderungan sejarah. Untuk memperoleh sejarah deskriptif yang komprehensif, penelitian ini hanya menelusuri arsip-arsip, terutama mengkaji laporan kredit dalam volkscreditwezen, Laporan otoritas Algemeene Volkscreditbank (AvB), Laporan Tahunan Bank Rakyat Indonesia (BRI) dan data 
kemiskinan. Selanjutnya, penelusuran dilanjutkan dengan pengkajian arsip laporan kolonial yang terjangkau serta sumber- sumber sekunder lain, seperti koran, majalah, ataupun jurnal. Hasil desk study di atas kemudian dilakukan analisis berdasarkan kronologi faktualnya (Shafer, 1974).

Tahapan ini menjadi dasar merekonstruksi sejarah dengan melihat berbagai data untuk melihat strukturnya. Oleh karena itu, penelitian ini lebih melihat indikator-indikator kausatif dan kecenderungan praktik kredit dengan mendasarkan pada model ekonomi yang dualistik. Indikator utama yang dilihat adalah latar belakang dan aplikasi kebijakan kredit, jumlah angka tunggakan kredit, penyusutan jumlah bank-bank desa, dan struktur kelembagaan ekonomi. Indikator tersebut dimungkinkan akan dapat merekonstruksi bagaimana kredit dan sistem kredit merupakan cara mempertahankan dualisme ekonomi.

\section{KEBIJAKAN DAN SISTEM KREDIT DI YOGYAKARTA AWAL ABAD XX}

Sejak berkembangnya kredit rakyat di Yogyakarta tahun 1912 sampai sekitar depresi 1930-an telah banyak memunculkan kritik, terutama terkait persoalan ekonomi pedesaan. Di Yogyakarta kritik itu pernah terjadi yakni yang ditujukan kepada Alegemeene Volkscreditbank $(A V B)$. Kritikan tajam pada awal peluncuran kredit petani di Yogyakarta tahun 1935 ditujukan kepada Fruin yang pada waktu itu menjadi Presiden $A V B$ yang berdiri tahun 1934. $A V B$ ini kemudian berubah menjadi Bank Rakyat Indonesia (BRI). Berdirinya $A V B$ dianggap memberikan peluang bagi kemunduran ekonomi petani Yogyakarta, terutama setelah Bank Desa dengan program Kredit Usaha Pedesaan (Kupedes) diluncurkan pertama kali pada tahun 1968. Dalam sebuah artikel yang ditulis W. Middendorp yang berjudul "Critical Review of the Village Credit System", yang dikutip oleh Kuiper, disebutkan di pedesaan Yogyakarta sampai tahun 1968 tidak ada Bank Desa terpercaya yang mampu memberikan pelayanan kredit terhadap petani (Kuiper, 2003; Schmit, 1999). Hal ini sangat berbeda jauh, jika dibandingkan dengan praktik kredit sebelum tahun 1930. Paling tidak, ada dana hampir $4 \%$ dari total dana yang tersedia di Bank Desa tersalurkan ke kelompok kecil petani dan usaha mikro sebagai dana bantuan yang menguntungkan. Periode setelah tahun 1930-an menunjukkan bahwa dari total dana 4\% dari Bank Desa untuk penyaluran kredit, yang tersalurkan dengan mekanisme kredit rakyat hanya 1,2\%. Pada tahun 1934 persediaan dana pada Kas Sentral (Central Fund) yang disediakan pemerintah tiap tahun mencapai f2.875.000 yang ditransfer ke tiap provinsi yang memiliki $A V B$. Kewajiban pengembalian dana ke pemerintah oleh $A V B$ hanya dilakukan pada saat jatuh tempo obligasi tiap tahun. Dengan bunga bank rata-rata $3,17 \%, A V B$ mampu mengembalikan $\mathrm{f} 2,125,250$ dari dana cadangan dan masih tersisa sebagai dana kas sebesar 3,22\% atau sekitar 7750.000 . Dengan sistem seperti itu, $A V B$ mampu mengembalikan dana cadangan ke pemerintah tiap tahun. Namun, jika ditelusuri lebih lanjut, sistem pengucuran dana dari Kas Sentral (Central Fund) ke $A V B$ membuat $A V B$ harus mencari jalan untuk mendapatkan debitur seluas-luasnya dengan mengucurkan dana kredit ke petani dan usaha mikro. Inilah yang kemudian, menurut Boeke, yang menyebabkan munculnya dualistic trade and dualistic money traffic (Boeke, 1953:113-137). Jika pengembalian dana dari $A V B$ ke Kas Sentral hanya dikenai bunga sebesar 3,17\%, $A V B$ menarik bunga dari sistem kredit rakyat rata-rata $8 \%$.

Laporan tahun 1942 yang terangkum dalam majalah bulanan Volkscredietwezen yang terbit tahun 1913-1942 menunjukkan perkembangan kredit rakyat di tingkat pedesaan yang cepat. Jika dilihat dari sekala Jawa dan Madura khususnya tahun 1917-1933, dapat terlihat data di bawah ini.

Tabel 1

Sistem Bank Kredit Rakyat Jawa dan Madura (dalam 1000 gulden)

\begin{tabular}{cccccc}
\hline $\begin{array}{c}\text { Akhir } \\
\text { Tahun }\end{array}$ & IGCI & $\begin{array}{c}\text { Jumlah } \\
\text { desa }\end{array}$ & Total & $\begin{array}{c}\text { Dana yang } \\
\text { dipinjamkan } \\
\text { tiap Bank Desa }\end{array}$ & $\begin{array}{c}\text { Jumlah } \\
\text { Bank Desa }\end{array}$ \\
\hline 1917 & 6.046 & 3.206 & 9.252 & 1,250 & 2.107 \\
1921 & 9.341 & 6.097 & 15.438 & 1,911 & 2.261 \\
1925 & 12.432 & 10.072 & 22.504 & 5,461 & 4.307 \\
1929 & 16.422 & 15.418 & 31.840 & 8,049 & 5.666 \\
1931 & 20.691 & 16.897 & 37.588 & 5,382 & 6.144 \\
1932 & 20.052 & 18.395 & 38.477 & 3,424 & 6.246 \\
1933 & 20.292 & 16.834 & 37.126 & 3,122 & 6.264 \\
\hline
\end{tabular}

Sumber: diolah dari Dr. C.F. Scheffer (1951) dan Volkscreditwezen, 1942. IGCI adalah Local Council Credit Institution, Dewan Lembaga Kredit Lokal. 
Peningkatan pengucuran dana dan jumlah peminjam mengindikasikan keberhasilan pemerintah untuk menghimpun dana dari masyarakat. Jika dilihat dari besaran rata-rata bunga dari Bank Desa pada tahun 1930-1931 adalah $8 \%$, sebenarnya beban petani dan usaha kecil tidak bertambah ringan. Bunga $8 \%$, jika diambil dan dibayarkan rerata dari penghasilan yang kurang dari 2 gulden semakin memberatkan karena petani harus juga menanggung pajak dan sewa (Kurasawa, 1993). Oleh karena itu, jumlah peminjam yang meningkat pada tahun 1930-an itu adalah peminjam yang bermodal menengah ke atas. Hal ini dapat dilihat dari tujuan peminjaman yang meningkat jumlahnya adalah peminjam dengan tujuan membeli rumah, perbaikan rumah, sedangkan untuk pembelian hewan ternak, penyewaan tanah menurun. Di samping penerima pinjaman kredit adalah mereka yang bermodal menengah dan atas, juga diberikan untuk kelompokkelompok sektor saja, misalnya kelompok nelayan (Semedi, 2003:66, 90, 104; Masyhuri, 1996) dan kelompok petani. Hal ini dimaksudkan untuk efisiensi biaya penyaluran, risiko tunggakan, dan jaminan pengawasan. Kemiskinan dan sulitnya mengkases Bank Desa banyak ditemukan pada masyarakat pedesaan Gunungkidul, Kulonprogo, terutama periode 1940-an (Kurasawa, 1993:4345). Bagi masyarakat petani yang tidak memiliki kelompok sektoral, sangat sulit untuk mengakses kredit, apalagi data-data pelaksanaan pengucuran dana kredit sering didasarkan pada hubungan patron- clientship dengan kepala desa sebagai orang yang bertanggung jawab terhadap Bank Desa maupun Lumbung Desa (Djojohadikusumo, 1989).

Kritikan tajam Timmer dalam melihat datadata laporan pemerintah sebelum tahun 1950- an mengindikasikan kesenjangan ekonomi yang terjadi di Yogyakarta (Timmer, 1961:392). Tingginya bunga Bank dan menurunnya pendapatan petani dan usaha mikro di Yogyakarta mengakibatkan terjadinya kelangkaan berbagai barang kebutuhan sehari-hari di satu sisi, tetapi juga mengakibatkan tunggakan pinjaman yang semakin banyak di sisi lain (White, 2004; Yuniver dan Meuleneare, 2000).

Untuk menunjukkan tingginya bunga Bank pada tahun 1928-1933, di bawah ini disajikan perkembangan bunga Bank sebagai berikut.
Tabel 2

Bunga Bank dan Tunggakan Kredit 1928-1933

\begin{tabular}{cccc}
\hline Tahun & Bunga Bank & $\begin{array}{c}\text { Jumlah } \\
\text { Tunggakan } \\
\text { (f 1.000) }\end{array}$ & $\begin{array}{c}\text { \% dari Jumlah } \\
\text { Pinjaman Berjalan }\end{array}$ \\
\hline 1928 & $<12 \%$ & 3.206 & 9.252 \\
1929 & $12 \%$ & 6.097 & 15.438 \\
1930 & $15 \%$ & 10.072 & 22.504 \\
1931 & $18 \%$ & 15.418 & 31.840 \\
1932 & $<24 \%$ & 16.897 & 37.588 \\
1933 & $<24 \%$ & 18.395 & 38.477
\end{tabular}

Sumber: Djojohadikusumo (1989:113); Wasino (2003:289290)

Data diatas menunjukkan bahwa peningkatan bunga kredit berbanding lurus dengan peningkatan jumlah peminjam dan tunggakan kredit. Hal ini menunjukkan bahwa debitur yang memiliki kemampuan membayar bunga di atas $15 \%$ lah yang dapat memanfaatkan dan mendapatkan dukungan fasilitas kredit dari pemerintah, walaupun tidak diikuti dengan daya pengembalian kredit yang baik. Subsidi pemerintah terlalu banyak terserap di sektor perkreditan untuk menyokong stabilisasi ekonomi kredit dengan bunga di atas $15 \%$. Kondisi itulah yang kemudian menyebabkan kredit dan sistem perbankan masih tetap berjalan walau dana tunggakan cukup tinggi untuk rata-rata di Jawa.

Pada awal pendirian Bank Desa, pemerintah mengucurkan dana sekitar f1.495.951,03 untuk keperluan pemberian kredit. Dana itu tidak seluruhnya diperuntukkan penyaluran kredit, tetapi harus dibagi untuk dana pendirian bank sebagai cadangan dan sebagian untuk kredit rakyat. Cadangan dana pemerintah untuk pendirian Bank Kredit sebesar f1.482.198,12 dan khusus untuk kucuran kredit dan pembelian barang-barang hanya sebesar f13.753,91 (ENI, 1921:608). Jika dilihat total pengeluaran uang yang dikucurkan, pelayanan kredit hanya mencapai $1,2 \%$ dari total pendanaan fasilitas kredit termasuk dana untuk pendirian bank.

Bank Desa yang merupakan cara kolonial Belanda untuk meningkatkan daya ekonomi masyarakat pedesaan yang dibentuk tahun 1904 sebenarnya menjadi dasar untuk menganalisis seberapa jauh perputaran uang dan mekanisme survival strategy masyarakat pedesaan dalam masa sebelum dan sesudah Depresi 1930. Namun, pelacakan sumber-sumber terkait laporan resmi dari 
AVB dan Javasche Bank belum mengindikasikan berbagai hal terkait kebijakan kredit dan respon kredit rakyat pedesaan Yogyakarta lebih rinci.

Pada saat setelah Depresi 1930, jumlah praktik perbankan di pedesaan Yogyakarta berdasarkan Laporan Tahunan Bank Desa Tahun 1933 menunjukkan bahwa di Yogyakarta telah terdapat sejumlah bank yang tersebar di beberapa kabupaten sebagai berikut.

Tabel 3

Luasan dan Jumlah Bank Desa di Yogyakarta Tahun 1933

\begin{tabular}{cccc}
\hline Kabupaten-Kota & $\begin{array}{c}\text { Jumlah } \\
\text { Desa }\end{array}$ & $\begin{array}{c}\text { Jumlah } \\
\text { Bank Desa }\end{array}$ & $\begin{array}{c}\text { Jumlah } \\
\text { Lumbung Desa }\end{array}$ \\
\hline Yogyakarta & 149 & 147 & 147 \\
Bantul & 147 & 151 & 151 \\
Gunungkidul & 274 & 57 & 57 \\
Adikarto (Brosot) & 168 & 50 & 50 \\
Kulonprogo & 119 & 83 & 83
\end{tabular}

Sumber: Verslag van Het Volkscredietwezen over 1933 met 17 Bijlagen, Uitgave van de Alegmeene Volkscreditbank: (Batavia Centrum, Albrechte.Co, 1934), hlm. 68.

Data di atas menunjukkan persebaran jumlah Bank Desa dan Lumbung Desa yang dilaporkan sama jumlahnya karena keduanya merupakan lembaga perkreditan pedesaan yang memiliki satu manajemen dengan berpraktik dua kegiatan kredit, yaitu kredit berupa hasil panen (padi), in natura dan kredit berupa pinjaman uang, in cash. Oleh karena itu, Bank Desa dan Lumbung Desa pada periode sebelum dan setelah Depresi 1930 dianggap satu lembaga dan berada pada manajemen yang sama di bawah kepala desa. Pada tahun 1934, keduanya berada di bawah pengawasan $A V B$ (Creutzberg and van Laanen, 1980:40). Alasan lain, jumlah Bank Desa dan Lumbung Desa sama dikarenakan adanya pelaporan dari kepala Bank Desa yang memberikan informasi kepada komisaris Javasche Bank bahwa keadaaan Bank Desa harus dilaporkan sebagai bank yang sehat.

Laporan komisari Javasche Bank sangat jelas tampak bagaimana kebijakan kredit rakyat selalu hanya merupakan cara kolonial untuk menarik dana masyarakat dan seolah-olah tidak ada masalah terkait dengan penyaluran kredit rakyat. Di sisi lain, laporan-laporan yang dibuat oleh komisaris Javasche Bank seringkali ditemui beberapa hal yang janggal, seperti terlihat dalam beberapa neraca perbankan di Yogyakarta yang dilaporkan oleh Komisari Javasche Bank, W.G. Bisschop, di bawah Departemen Keuangan dari tahun 1915-1921 sebagai berikut.

Tabel 4

Neraca Keseimbangan Keuangan di Yogyakarta Berdasarkan Laporan Komisaris Javasche Bank Tahun 1915-1921

\begin{tabular}{cccc}
\hline Tahun & Debet & Kredit & Saldo \\
\hline 1915 & $\mathrm{f} 120.702,77$ & $\mathrm{f} 118.302,77$ & $\mathrm{f} 2.400$ \\
1916 & $\mathrm{f} 162.605,84$ & $\mathrm{f} 163.604,84$ & 0 \\
1918 & $\mathrm{f} 226.043,90$ & $\mathrm{f} 226.043,90$ & 0 \\
1919 & $\mathrm{f} 534.227,02$ & $\mathrm{f} 550.227,02$ & $-\mathrm{f} 16.000$ \\
1921 & $\mathrm{f} 1.293 .397,99$ & $\mathrm{f} 1.293 .397,99$ & 0 \\
\hline
\end{tabular}

Sumber: ANRI, Laporan Javasche Bank, (Departemen Keuangan, 1921); ANRI, Laporan Raad van Commissarissen balans en wints Versliesrekening der Javasche Bank over het 925 te Bookjaar 1919-1920.

Data di atas menunjukkan bahwa Javasche Bank dalam melaporkan neraca keuangan ke Kas Sentral, terutama semenjak berdirinya Bank Kredit Rakyat di Yogyakarta tahun 1912, selalu menunjukkan neraca ekonomi yang sehat. Padahal jika dilihat lebih dalam, jelas sekali bahwa Javasche Bank sangat terbebani dengan pengembalian pinjaman dari Bank Desa yang telah mengucurkan dana pinjaman untuk petani dan masyarakat desa. Pinjaman terberat terutama berupa pinjaman jangka pendek, yaitu mingguan dan bulanan (lapanan), sedangkan jangka panjang yang berbentuk pinjaman musiman tidak begitu membebani Jacavshe Bank ketika harus mengembalikan dana ke Kas Sentral (Djojohadikusumo, 1989).

Beban berat para debitur pedesaan adalah jenis pinjaman mingguan dan bulanan yang sangat sulit dikembalikan tepat waktunya karena para kreditur pedesaan lebih menggunakan hasil pinjmanannya untuk konsumsi, penggarapan sawah, perbaikan rumah dan pembelian hewan ternak, sedangkan untuk jenis pinjaman berjangka musiman, para kreditur pedesaan lebih mampu mengembalikan karena mereka membayar pada saat habis panen (Djojohadikusumo, 1989:200201). Pada umumnya, Bank Desa memberikan pinjaman kredit pada petani pemilik lahan dan usaha peternakan rata-rata di atas f20 yang mereka fungsikan untuk penggarapan lahan, biaya 
penanaman, pembelian hewan ternak, termasuk kuda, unggas, itik, penebusan barang-barang gadai. Sementara itu, untuk pinjaman usaha pertanian dengan sekala kecil dan perdagangan kecil sangat terbatas. Berbeda dengan petani pemilik lahan, petani yang tidak memiliki tanah hanya diperbolehkan meminjam maksimum f5 bisa dibayar mingguan ataupun bulanan (Fruin, 1933:23-24).

Menjelang kedatangan Jepang di Yogyakarta, banyak petani yang tidak memiliki hak milik tanah (eigendom), tetapi hanya hak guna tanah (gaduh). Hal ini terjadi karena masih terikat oleh peraturan Rijksblad Yogyakarta no. 16 Tahun 1918, yaitu semua tanah kecuali tanah lungguh merupakan tanah-tanah untuk industri gula dan para petani hanya diberi hak pakai dengan sistem glebagan sebesar 1 petak sawah untuk digarap sebagai sawah padi (1.250 ha) (Kurasawa, 1993:43). Dengan model pinjaman kredit yang tidak seimbang ini, banyak pinjaman yang sulit dikembalikan, terutama oleh petani penggarap yang berpola mingguan dan bulanan. Kritikan tajam ketidakseimbangan ini muncul dari Feldmann yang menyimpulkan bahwa (1) praktik kredit rakyat 1930-1940-an masih berpraktik memakai mekanisme kapitalistik; (2) pemberi jasa pinjaman terutama Bank Pemerintah (Bank Desa dan Gadai) masih seperti memakai sistem dan mekanisme lama dengan menggunakan sistem "barter", pertimbangan peredaran uang (cash flow) dan jumlah barang yang beredar lepas dari perhitungan bank; (3) dalam praktik kredit pedesaan, perbankan tidak memperhatikan sistem ekonomi holistik (holistic-economic system), yaitu pertimbangan hubungan ekonomi dan budaya kurang diperhatikan (Feldmann, 1949:136-151). Para penganut aliran Boeke tetap mencari-cari bukti bahwa sistem kredit adalah suatu cara menciptakan shared poverty baru. Data berikut menggambarkan kenaikan tunggakan kredit yang berhasil dihimpun Djojohadikusumo. Djojohadikusumo mencatat ada beberapa bank yang mengalami tunggakan cukup berat antara tahun 1929-1937.
Tabel 5

Tunggakan dan Prosentase Pinjaman yang Belum Lunas di Jawa dan Madura

\begin{tabular}{ccc}
\hline No & Prosentase & Jumlah Kabupaten \\
\hline 1 & $<1 \%$ & 21 \\
2 & $1-5 \%$ & 20 \\
3 & $5-20 \%$ & 21 \\
4 & $20-40 \%$ & 6 \\
5 & $>40 \%$ & 4 \\
\hline
\end{tabular}

Sumber: Djojohadikusumo (1989:206)

Khusus Jawa, di antara Jawa Tengah, Jawa Barat, dan Jawa Timur, tunggakan yang paling tinggi adalah Jawa Tengah termasuk di dalamnya daerah Yogyakarta. Untuk Jawa Tengah dan Yogyakarta, tunggakan Bank Desa pada tahun 1929 mencapai $1 \%$, tahun 1933 mencapai $21,5 \%$ dan $2,7 \%$ pada tahun 1937. Jika dibandingkan dengan Jawa Barat, pada tahun 1929 tunggakan Bank Desa hanya $0,4 \%$, pada tahun 1933 mencapai $1,9 \%$ dan $0,3 \%$ untuk tahun 1937, sedangkan Jawa Timur 0,3\% pada tahun 1929,11,4\% tunggakan tahun 1933, dan 1,4\% tunggakan tahun 1937. Kalau dilihat dari prosentase jumlah pinjaman sampai tahun 1940an, dari total beaya kas yang diperuntukkan kredit rakyat (volkscreditbanken) hanya $23 \%$, sedangkan untuk Pegadaian (pandhuizen) 34\% dan Bank Desa (dorpsbankjes) 37\% (Scheffer, 1951:31).

Indische Verslag tahun 1941 melaporkan beberapa kejadian di Yogyakarta, terutama setelah Depresi tahun 1930-an. Banyak kreditur datang ke pedesaan untuk membeli tanah-tanah di pedesaan Yogyakarta dengan cara kredit. Pembayaran kembali akan dilakukan ketika tanah-tanah mereka sudah menghasilkan, seperti tebu untuk kasus industri gula. Menyempitnya lahan persawahan dikarenakan untuk perkebunan tebu, dan harga beras turun pada tahun 1933-1940-an, lebih rendah daripada tahun 1926-1929 yang membuat petani lebih memilih menjual tanah-tanahnya kepada kreditur karena kebutuhan akan uang untuk mencukupi kebutuhan sehari-hari. Pada periode depresi ini terkenal dengan zaman tuku dhuwit (zaman beli uang) dan atau zaman larang dhuwit (zaman uang mahal). Istilah zaman tuku dhuwit maupun zaman larang dhuwit dimaksudkan sebagai zaman beban ekonomi petani pemilik tanah yang semula mendapatkan hasil dari tanahnya dan dapat membayar pajak menjadi tidak mampu 
lagi membayar pajak karena mereka terbebani pajak tanah yang sangat terkait dengan pajak somah (household tax) (Kuiper, 2003:14). Mereka menyerahkan tenaga kerjanya sebagai pengganti pajak karena tidak memiliki uang.

Kurasawa menunjukkan akibat gempuran Depresi Gula 1930-an terhadap petani penggarap dan pemilik tanah sempit (1 petak) mengalami kesulitan ekonomi yang sangat berat walaupun mereka tidak lagi disibukkan dengan urusan air irigasi dan tidak cemas apakah tanah-tanah mereka dikembalikan pada waktu habis sewa atau tidak. Untuk tanah-tanah di sekitar perkebunan dan pabrik gula, muncul persoalan baru, yaitu munculnya kelompok-kelompok petani kuli karang kopor, kuli gamblok, dan indon, kecuali beberapa daerah termasuk pedesaan sekitar Desa Tumus, Desa Sidomulyo muncul kuli kenceng. Kasus daerah industri gula dan yang terkena dampak langsung industri gula, pada pada tahun 1943 dilaporkan rata-rata desa memiliki jumlah kuli karang kopor, kuli gamblok, indon sekitar $47 \%$ dari total penduduk masing-masing desa atau sekitar 48 KK sampai 184 KK per desa. Walaupun kemunculan kelompok kuli ini diperkirakan sudah ada sejak masa Kolonial Belanda, namun pertambahan jumlah mereka setelah Depresi 1930 sampai kehadiran Jepang pada tahun 1943 mengalami peningkatan (Kurasawa, 1993:46).

Beban berat petani ini bertambah dengan peningkatan dan standardisasi harga ternak dalam hal ini ternak untuk kerja sawah dan potong yaitu sapi. Hal ini menyebabkan para petani banyak yang tidak mampu membeli sapi untuk kerja sawah. Harga sapi di Yogyakarta pada masa pendudukan Jepang berdasarkan Makloemat Gunseikan No. 59 tentang menetapkan harga penjualan yang paling tinggi ternak, ternak bersayap, daging dan susu. Untuk sapi pekerja dengan kategori umur di atas 24 bulan jenis unggul harganya f.110 sedangkan jenis lain hanya 990 . Sapi potong dengan umur di atas 24 bulan dibagi menjadi dua kategori yaitu, untuk berat diatas $150 \mathrm{~kg}$ harganya $\mathrm{f}, 19 / \mathrm{kg}$, sedangkan berat di bawah $150 \mathrm{~kg}$ dipatok harga f0,18/kg. Anak sapi yang berumur 6-12 bulan dihargai f0,23/ $\mathrm{kg}$, kurang dari 6 bulan f0,24/kg, dan antara 1224 bulan dihargai f0,21/kg (Kan Po, 2604:6-12). Beban itu belum lagi ditambah pajak dan sewa rumah di luar kota Yogyakarta yang mencapai f81/tahun, kalau dalam kota f192/tahun (Kan Po, 2604:6-7).

\section{KEBIJAKAN KREDIT DAN EKONOMI SUBSISTEN PASCA KEMERDEKAAN}

Sampai tahun 1955, kondisi ekonomi yang merupakan hasil dari kebijakan kredit rakyat tidak berubah. Studi Timmer tentang kematian bayi pada periode 1930-1955 menunjukkan masih tingginya tingkat kemiskinan di pedesaan Yogyakarta (Timmer, 1961). Timmer mengukur kemiskinan dengan menggunakan jumlah konsumsi kalori penduduk miskin di Yogyakarta. Oleh karena itu, dalam tulisan ini, indikator konsumsi kalori dan protein dipakai sebagai salah satu cara menunjukkan kemiskinan, terutama di Yogyakarta, di samping indikator-indikator yang tersebut sebelumnya. Tabel di bawah ini menunjukkan bahwa rata-rata konsumsi kalori dan protein di daerah penelitian dianggap rendah dengan sekala penghitungan standar rata-rata cukup kalori di atas 2000 kkal.dan 50,25 untuk protein.

Tabel 6

Jumlah Konsumsi Kalori dan Protein di Yogyakarta 1955 (perorang/hari)

\begin{tabular}{ccc}
\hline Kabupaten & $\begin{array}{c}\text { Jumlah konsumsi } \\
\text { kalori/hari }\end{array}$ & $\begin{array}{c}\text { Jumlah konsumsi } \\
\text { protein/hari }\end{array}$ \\
\hline Sleman & 1790 & 36 \\
Bantul & 1124 & 22 \\
Kulonprogo & 907 & 16 \\
Gunungkidul & 1724 & 29 \\
\hline Sumber: Timmer $(1961 \cdot 391)$ &
\end{tabular}

Menurut Timmer, kepedulian Pemerintah untuk mengucurkan dana kredit di Yogyakarta sampai tahun 1950-an, telah banyak yang berhenti di sektor industri menengah dan besar, sedangkan pengucuran dana kredit di Yogyakarta yang disetujui biasanya hanya $1 / 3$ dari pengajuan pinjaman dan itupun hanya cukup untuk beaya produksi (Timmer, 1961:474-475).

Upaya untuk memberikan bantuan kredit pada tahun 1950 kepada anggota koperasi dengan membentuk Garantie Fonds dengan jumlah dana Rp.5.000.000 tidak terlaksana akibat adanya aksi-aksi militer. Untuk mengatasinya, Wakil Presiden Moh. Hatta dengan berbagai pertimbangan meminta Sekretaris Jenderal 
Kementrian Keuangan Ir. Teko Soemodiwirjo untuk mengucurkan dana bagi nelayan sebesar Rp2.500,00 (ANRI:KPMRI, 1950). Kucuran dana untuk nelayan ini merupakan bentuk gerakan koperasi nelayan yang merupakan kelompok masyarakat yang tidak terkena dampak langsung dari perubahan kebijakan keuangan. Melalui surat dari BNI atas respons surat dari Kementrian Kemakmuran RIS, diputuskan peraturan mengenai pinjaman koperasi, yaitu pinjaman yang berjangka 10 tahun yang dicontohkan dalam surat tersebut akan diwajibkan membayar cicilan dan bunga 10\%. Jika debitur meminjam Rp6.424.700, total pembayarannya adalah $10 \times 12 \times 6.424 .700,00$ $=\mathrm{Rp7}$.200.000,00. Jumlah bunga yang harus dibayar $10 \times 6.424 .700,00=\mathrm{Rp} 642.470,00$. Jadi, pengembaliannya Rp6.424.700,00 + Rp. $642.470,00=\operatorname{Rp} 7.200 .000,00$

Di samping peraturan itu semakin memberatkan kelompok petani maupun nelayan, juga uang yang berlaku di Yogyakarta adalah uang Jepang, URI (sic) dan Streits-dollar (ANRI: KPMRI, 1950). Bahkan, sejak ide regulasi perkreditan petani dan nelayan di Yogyakarta disosialisasikan sejak 1947, Sultan Hamengku Buwana IX, telah mengantisipasi dengan memunculkan sistem kredit baru, yaitu Jajasan Kredit Tani (Jakti) yang dididrikan di Yogyakarta 17 Maret 1954 (Arsip Sekretariat DPRD Jogja, 1954). Jakti ini didirikan untuk membantu petani tembakau virginia dan Vorstenlanden di Yogykarta. Namun akibat sistem manajemen dan maladministrasi, Jakti akhirnya tidak dapat berkembang bahkan sampai masuk dalam ranah hukum. Pada tahun 1955 mendorong anggota Dewan Perwakilan Rakyat Daerah Yogyakarta melakukan mosi tidak percaya pada Susanto, anggota Dewan Pertimbangan Daerah, dan akhirnya Jakti tidak bisa melaporkan kegiatannya dan meneruskan program kreditnya. Keberadaan Jakti sebenarnya oleh Sultan HB IX dimaksudkan untuk meningkatkan taraf hidup dan kemudahan pengelolaan industri tembakau bagi petani tembakau yang berada dalam anggota VOTP (Vak Organisasi Tani Primair) (Selo soemardjan, 1962:292). VOTP ini merupakan wadah pelayanan kredit bagi petani tembakau, tetapi pada masa-masa berikutnya petani diluar VOTP juga dibolehkan mengajukan kredit. VOTP ini dibentuk di Kulonprogo dan Gunungkidul dengan pertimbangan mayoritas petani tembakau berada di Kulonprogo dan Gunungkidul.

Melalui BRI, Jakti memperoleh dana proyek sebesar Rp23.000.000,00 sebagai modal kredit. Pengucuran dana ini oleh Kementrian Keuangan disyaratkan semua produk tembakau dari petani yang berada di bawah Jakti harus dijual ke $B A T$ (British American Tobacco Company). Persyaratan tersebut tampaknya disetujui dan pada tahun 1955, tetapi kelompok Anti- Komunis, Masyumi menuduh Jakti sebagai kaki tangan komunis dan tidak bertanggungjawab terhadap keuangan Pemerintah. Pada tahun 1958, dibentuklah "Jakti Baru" yang lebih memberikan pelayanan bagi anggota petani tembakau yang tergabung dalam VOTP. "Jakti Baru" ini memiliki 36 anggota usahawan dibidang koperasi yang kemudian mereka diakui pemerintah (Selosoemardjan, 1962:292).

Untuk pelayanan kredit pedesaan, sejak tahun 1965 di Yogyakarta, ada 18 unit yang tersebar di Sleman ada 6, Bantul ada 3, Gunungkidul ada 5 dan Kulonprogo ada 4. BRI Unit Desa ini melayani pedesaan Yogyakarta (Laporan Tahunan BRI, 1971). Tabel di bawah ini menunjukkan daftar pinjaman berdasar pada jadwal peminjaman.

Tabel 7

Jumlah Pinjaman Program Bimas pada Awal Pendirian BRI Unit Desa, Yogyakarta 1965-1969

\begin{tabular}{|c|c|c|}
\hline Musim & $\begin{array}{c}\text { Volume Pinjaman } \\
\text { (Juta Rp) }\end{array}$ & Pemberi Kredit \\
\hline 1965/66 (basah) & 2.2 & BRI \\
\hline 1966 (kering) & $\mathrm{tt}$ & $\mathrm{tt}$ \\
\hline 1966/67 (basah) & 6.0 & $\begin{array}{l}\text { PN Pertani, } 100 \% \\
\text { dalam bentuk kredit, } \\
\text { repayment } 10 \%\end{array}$ \\
\hline 1967 (kering) & $\mathrm{tt}$ & $\mathrm{tt}$ \\
\hline 1967/68 (basah) & 30.6 & $\begin{array}{l}\text { BRI, } 81 \% \text { dalam } \\
\text { bentuk kredit }\end{array}$ \\
\hline 1968 (kering) & 24.3 & $\begin{array}{l}\text { BRI, } 77 \% \text { dalam } \\
\text { bentuk kredit } \\
\text { BRI, } 70 \% \text { dalam }\end{array}$ \\
\hline 1968/69 (basah) & $37.5^{*}$ & $\begin{array}{l}\text { bentuk kredit; } \\
\text { repayment } 83 \%\end{array}$ \\
\hline 1969 (kering) & $2.5^{* *}$ & $\begin{array}{l}\text { BRI, } 80 \% \text { dalam } \\
\text { bentuk kredit; } \\
\text { repayment } 74 \%\end{array}$ \\
\hline \multicolumn{3}{|c|}{$\begin{array}{l}\text { *)Laporan asli 35.5; tahun } 1971 \text { BRI Yogyakarta menggunakan } \\
\text { data } 37.5 \text { and BRI-Jakarta menggunakan data } 42.5 \\
\text { **)Data BRI Yogyakarta; data resmi BIMAS adalah 2.9; lihat } \\
\text { Kuiper (2003) }\end{array}$} \\
\hline
\end{tabular}


Data di atas dipakai Kuiper untuk menunjukkan bahwa pengembalian pinjaman (loan repayment) mencapai rata-rata antara $70-85 \%$. Ini artinya kredit yang ditawarkan BRI mendapat respons positif dari masyarakat. Berbeda halnya dengan PN Pertani yang hanya mencapai $10 \%$. Bahkan, loan repayment itu dibayar tepat waktu tidak melebihi normal waktu pinjaman sampai 7 bulan.

Untuk memperlancar jalannya pinjaman bagi petani, BRI dan Bimas (Bimbingan Masyarakat) menggunakan Koperta (Koperasi Pertanian) untuk menyosialisasikan layanan kreditnya. Biasanya Koperta ini di ketuai oleh Kepala Desa atau Mantri pertanian. Pada saat Yogyakarta dijadikan Pilot Project tahun 1969 untuk menyelenggarakan sistem kredit rakyat, Menteri Pertanian, Kepala BRI dan PN Pertani menyetujui dibentuknya sistem kredit baru bernama Bimas Gotong Rojong yang mulai dijalankan pada Rencana Pembangunan Lima Tahun I (Repelita I), 1969-1974. Program baru ini akan memberikan kemudahan pelayanan keuangan di wilayah pedesaan dengan merehabilitasi Bank Kredit Desa (BKD) yang berjumlah $5.000 \mathrm{di}$ Yogyakarta di bawah supervisi BRI. Dana yang tersedia untuk merehabilitasi secara nasional berjumlah Rp2.000.000,00 untuk 20.000 BKD. Program ini juga dilengkapi dengan sarana prasana yang cukup lengkap termasuk Mobile Unit (MU), sedangkan PN Pertani dipersilahkan mencari kebebasan untuk mencari nasabah dengan berkompetisi dengan para pedagang dan kredit informal di Yogyakarta.

Bimas ini dalam perkembangannya sampai tahun 1972 telah mendirikan gudang penyimpanan sejumlah 16 di seluruh Yogyakarta. Di samping padi, juga hasil tanaman polowijo dan gaplek, terutama di daerah-daerah kering seperti Gunungkidul, Bantul, dan Kulonprogo. Gudang penyimpanan ini dikelola oleh masyarakat dan di bawah pengawasan dari staf BRI. Keberhasilan BUUD dalam menggalang dana dan hasil pertanian pedesaan Yogyakarta, membuat pemerintah meluncurkan program kredit baru yang menggunakan nama Tabanas yang diluncurkan pertama kali di daerah Turi, Sleman tahun 1971. Tabanas menjadi gaya hidup baru masyarakat pedesaan Yogyakarta dan menjadi satu-satunya mengakses keuangan di BRI. Penciptaan model kredit rakyat tunggal dengan Tabanas dan BUUD, membuat masyarakat pedesaan terkotak- kotak dalam berbagai varian sosial ekonomi dan mereka kesulitan memperoleh fasilitas Tabanas dan BUUD kecuali memenuhi syarat tertentu (Priyambodo dan Suyanto, 1991:35-43). Tahun 1972-1973 diberi catatan khusus karena periode ini kenaikan dana masyarakat terlihat konstan dengan peningkatan kreditur yang rata-rata 200 orang untuk Taska dan Tabanas di hampir seluruh kabupaten dan kota di Yogyakarta (Statistik Daerah Istimewa Yogyakarta, 1973:91).

Sampai tahun 1971, rata-rata jumlah pinjaman di Yogyakarta dapat dilihat sebagai berikut.

Tabel 8

Jumlah Pinjaman di 18 Desa di Yogyakarta 19691971(1000)

\begin{tabular}{lcccc}
\hline \multicolumn{1}{c}{ Kabupaten } & Bantul & \multicolumn{1}{c}{ Sleman } & Kulonprogo & G. Kidul \\
\hline $\begin{array}{l}\text { Jumlah Unit Desa } \\
\quad \text { (UD) }\end{array}$ & 3 & 6 & 4 & 5 \\
$\begin{array}{l}\text { Peminjam: } \\
\text { a. } 1969 / 1970\end{array}$ & 4,937 & 8,412 & 3,001 & 8,935 \\
b. 1970 & 2,629 & 8,980 & 1,647 & 124 \\
c. $1970 / 1971$ & 9,178 & 15,975 & 4,686 & 9,132 \\
d. 1971 & 3,677 & 10,250 & 2,215 & 7 \\
\hline
\end{tabular}

Sumber: FAO dikutip dari Kuiper (2003), diolah dengan interpretasi data laporan BRI tahun 1971

Dari jumlah pinjaman lewat BRI Unit Desa di Yogyakarta selama 2 tahun pada awal Orde Baru itu rata-rata pengembalian pinjaman hampir mencapai 100\%. Kecuali pada tahun 1971 dan khususnya daerah Gunungkidul, pengembalian pinjaman mengalami kesulitan hingga tidak melebihi $35 \%$. Pada awal diluncurkan hampir semua pinjaman terbayarkan. Setelah kredit berjalan 2 sampai 3 tahun beban ekonomi (economic over burdened) mulai terasa. Data di bawah tampak sekali bagaimana perkembangan tunggakan justru terjadi pada tahun ke-3.

Tabel 9

Pengembalian Pinjaman (\%) pada 31 Desember 1971

\begin{tabular}{ccccc}
\hline Kabupaten & $\mathbf{1 9 6 9 / 7 0}$ & $\mathbf{1 9 7 0}$ & $\mathbf{1 9 7 0} / 7 \mathbf{1 9 7 1}$ & $\mathbf{1 9 7 1}$ \\
\hline Sleman & 98.77 & 94.90 & 90.06 & 58.51 \\
Bantul & 99.62 & 98.57 & 93.55 & 68.73 \\
Kulonprogo & 99.97 & 99.62 & 97.45 & 83.26 \\
Gunung Kidul & 94.39 & 97.45 & 82.75 & 35.29 \\
\hline
\end{tabular}

Sumber: Kuiper (2003) dan hasil olahan data-data Statistik

Daerah Istimewa Yogyakarta (1973) 


\section{KEBIJAKAN PEMERINTAH DAN KUKUHNYA EKONOMI DUALISTIK}

Pemerintah pada tahun 1983 mengeluarkan deregulasi 1 Juni 1983. Peraturan ini memiliki tujuan utama mengatur tata kelola perbankan dalam penyaluran kredit sektor prioritas yang mencapai $3 \%$ dan sektor prioritas tinggi mencapai $12 \%$. Hal yang penting dengan regulasi ini adalah kemampuan perbankan untuk memobilisasi dana masyarakat lebih dari 25\% dari tahun 1983-1988. Meningkatnya dana masyarakat yang terserap ini menyebabkan perbankan menggelontorkan kredit sampai mencapai 26\% per tahun. Pada tahun 1988, kembali lagi pemerintah mengeluarkan Paket 27 Oktober 1988 (Pakto 27, 1988) yang lebih mempercepat penarikan dana masyarakat dengan cara memberikan fasilitas semua pelaku perbankan termasuk BUMN dan Bank Perkreditan Rakyat (BPR). Pakto 27, 1988 ini dimanfaatkan pelaku perbankan dengan mendirikan bank di tingkat Desa. Desa mengalami konjungtur ekonomi dengan penyerapan dana yang sangat cepat. Hal ini karena semua bank harus menyalurkan kredit ke sektor usaha kecil sebanyak 20\% (Yogaswara dkk., 1994:10-19). Jika dihitung sejak 1969 sampai 1988, perhitungan inflasi rata-rata bagi Bank Indonesia mencapai 3\%. Artinya, beban inflasi ini sebagian besar dinikmati oleh nasabah besar yang memiliki hak pinjam di atas Rp100.000.000,00. Bahkan, kebijakan Pakto 27, 1988 telah memberikan kesempatan untuk membuka pinjaman sampai Rp300.000.000,00. Persoalannya adalah untuk kredit rakyat yang memiliki jaminan plafond sampai dengan Rp100.000.000,00 hampir tidak ditemukan dalam kelompok-kelompok petani dan usaha kecil di Yogyakarta sampai menjelang tahun 1990 (Trajutisna, 1990:27). Dengan bunga 12\% plus subsidi bunga $1,5 \%$, ditambah plafond diatas Rp5.000.000,00 harus dengan jaminan merupakan upaya peningkatan ekonomi dengan skema Kredit Rakyat yang tidak masuk akal.

Pada tahun 1983 dan sampai menjelang tahun 1990, pemerintah dan BRI dipastikan kehilangan jumlah dana pinjaman mencapai $75 \%$ dari dana yang dipinjam dan $40 \%$ dana administrasi yang sudah dianggap hilang. Tentu saja, data itu perlu diinterpretasi bahwa $75 \%$ sebagai loan losses menjadi pertimbangan bahwa ekonomi berbasis kredit kecil selalu menjadi fasilitas free-entry bagi perusahaan menengah ke atas untuk mengeruk dana masyarakat melalui sistem kredit. Artinya, semenjak Orde Baru, kredit yang berkembang adalah sistem kredit corporate dengan perusahaan- perusahaan yang dapat memanfaatkan batas minimal di atas Rp300.000.000,00, sedangkan kredit sekala kecil (Kredit Mini) antara Rp5.000.000,00 sampai Rp100.000.000,00 tidak berjalan karena lebih dipakai sebagai kredit consumer (subsisten).

\section{SIMPULAN}

Kajian kredit dan sistem kredit formal di Yogyakarta antara tahun 1912-1990 menunjukkan bahwa kredit, terutama kredit rakyat, tidak banyak memberikan dampak ekonomi yang signifikan. Pemerintah dalam mendorong ekonomi pedesaan dan masyarakat rentan melalui kredit rakyat masih terjebak dalam dua kepentingan, yaitu kepentingan pemilik modal dan masyarakat yang dalam perkembangannya, justru memosisikan kebijakan pemerintah ini condong memihak kepada pemilik modal. Bahkan, dalam periode Orde Baru, sistem kredit melalui berbagai lembaga keuangan formal pedesaan telah menjadi salah satu alat politik pemerintah. Kajian dualisme ekonomi Boeke dalam sistem kredit rakyat membuktikan bahwa kredit dan sistem kredit rakyat tidak pernah memberikan jalan keluar bagi ekonomi subsisten di Yogyakarta dan berakibat pada bertahannya beban ekonomi masyarakat pedesaan (economic over burdened). Perubahan rezim pemerintah tidak mengubah sistem ekonomi pedesaan yang berbasis kredit rakyat. Hasil kajian ini menunjukkan bahwa justru kebijakan pemerintah telah memperkuat terpeliharanya sistem ekonomi dualistik di pedesaan Yogyakarta.

\section{DAFTAR RUJUKAN}

Abdullah, Irwan. (2002). "Tantangan Pembangunan Ekonomi dan Transformasi Sosial: Suatu Pendekatan Budaya". Jurnal Humaniora, Volume XIV, No 3.

Bell, Daniel. (1978). The Cultural Contradictions of Capitalism. New York:Basic Books Inc. Pub. Boeke, J.H. (1936). Inleiding Tot De Economie Der Inheemsche Samenleving in Netherlandsch-Indie. Tweede Druk, LeidenAmsterdam: M.H.Stenfert Kroese's UitgeversMij. N.V. 
(1953). Economics and Economic Policy of Dual Societies; As Exemplified by Indonesia. Harlem: H.D. Tjeenk Willink N.V.

Creutzberg, P. and J.T.M. van Laanen. (1980). Changing Economic in Indonesia, Vol. 6, "Money and Banking 1816-1940". The Hague: Martinus Nijhoff Pub, B.F.

Djojohadikoesoemo, Sumitro. (1989). Kredit Rakyat di Masa Depresi. Jakarta: LP3ES.

ENI. (1921). Tweede Druk, D.G. Stibbe, Verde deel. Leiden:Martines Nijhoff, N.V.s'Gravenhage.

Feldmann, N.J. (1949). de Overheidsmiddelen van Indonesie: In Verband met de Dualistische Economie, Leiden: H.E. Stenfert Kroese's Uitgevers-Mij NV.

Fruin, Thomas A. (1933). "History, Present Situation and Problems of The Village Credit System 1897-1932". Terjemahan Klaas Kuiper, Volkscreditwezen, No. 22.

Furnivall, J.S. (1944). Netherlands India: A Study of Plural Economy, Cambridge: AT University Press.

Kan Po, No. 49, Tahun ke III, Boelan 8 (2604), Djakarta tanggal 25-boelan 6, Syoowa 19 (2604).

Kan Po, No. 19, Tahun II, boelan 5, Djakarta, 25-boelan 6, 2604.

Kuiper, Klaas. (2003). “Act or Accident?: The Birth of the Village Units", Research Report, electronic version. Lihat www.gdrc.org/icm/country/ indonesia-act-accident-doc.

Kurasawa, Aiko. (1993). Mobilisasi dan Kontrol: Studi Tentang Perubahan Sosial di Pedesaan Jawa 1942-1945, Jakarta: Grasindo.

Masyhuri. (1996). Menyisir Pantai Utara. Yogyakarta: Yayasan Pustaka Nusatama-Perwakilan KITLV.

Proyambodo, Daru dan Bagong Suyanto. (1991). “ Pemanfaatan dan Pelayanan Kredit Usaha Rakyat Kecil: Penelitian di Tiga Kecamatan, Provinsi Jawa Timur", Prisma, no. 11, Jakarta, LP3ES.

Scheffer, C.F. (1951). Het Bankwezen in Indonesie; Sedert Het uitbreken van De Tweede Wereledoorlog. Djakarta: Noordhoff-Kolff, N.V.

Selosoemardjan. (1962). Social Changes in Jogjakarta. Ithaca. New York: Cornell University Press.

Semedi, Pujo. (2003). Close to The Stone, Far From The Throne: A Story of a Javanese Fishing Community 1820's-1990's. Yogyakarta: Benangmerah.
Shafer, R.J. (ed.). (1974). A Guide to Historical Method. Illionis: The Dorsey Press.

Soegiarto, Heru Nugroho. (1993), "The Embededness of Money, Moneylenders and Moneylending in A Javanese Town", disertasi Ph.D. di Fakultas Sosiologi, Universitas Bilefeld, Jerman

Schmit, Leo. (1999). "A History of The "Volkscreditwezen" (Popular Credit System) 1895-1935". The Hague: Development Cooperation Information Department of The Ministry of foreign Affairs.

Statistik Daerah Istimewa Yogyakarta, 1973.

Timmer, M. (1961). "Child Mortality and Population Pressure in The D.I. Yogyakarta, Java, Indonesia: A Social Medical Study". Disertasi Vrij Universiteit, Amsterdam.

Trajutisna, A.A. (1990). "Studi Sistem Perkreditan Swadaya", Laporan Sementara. Yogyakarta: Pusat Peran serta Masyarakat.

Yogaswara, Herry dkk. (eds.). (1994) Kredit Untuk Rakyat, dari Mekanisme Arisan Sampai BPR. Bandung: Akatiga.

Yuniver, Ferry and Stephen D. Meuleneare. (2000). "Community Currency System and Credit Unions". Research report, YAPPIKAPartnership.

White, Ben. (2004). “Towards a Social History of Economic Crisis: Yogyakarta in the 1930's, 1960's and 1990's" dalam H. Sammuel dan H. Schulte Nordholt (eds), Indonesia in Transition; Rethinking 'Civil Society, 'Region' and 'Crisis'. Yogyakarta: Pustaka Pelajar.

\section{Sumber-Sumber Arsip}

ANRI. (1934). Verslag van Het Volkscreditwezen over 1933 met 17 Bijlagen, Uitgave van de Algemeene

Volkscreditbank: Batavia Centrum, Albrechte. Co. ANRI. (1921). Laporan Javasche Bank, Departemen Keuangan.

ANRI. Laporan Raad van Commissarissen balans en wints Versliesrekening der Javasche Bank over het 925 te Bookjaar 1919-1920

ANRI. (1950). KPMRI Jogja no. 223, tanggal 3 Djuni 1950.

ANRI. (1950). KPMRI Jogja no 224, tanggal 7 Djuli 1950

Arsip Sekretariat DPRD Yogyakarta. (1971). "Akte Pendirian Jajasan Kredit Tani 17 Maret 1954”. Laporan Tahunan Bank Rakyat Indonesia. 